\title{
Himalayan Warming and Climate Change in India
}

\section{Vadlamudi Brahmananda Rao1, Sergio Henrique Franchito1, Renato Orrú Pedroso Gerólamo1, Emanuel Giarolla1, Surireddi Satyavenkata Venkata Siva Ramakrishna², Bodda Ravi Srinivasa Rao ${ }^{2}$, Chennu Vankateswara Naidu²}

${ }^{1}$ Center for Weather Prediction and Climate Studies, INPE, São José dos Campos, S.P., Brazil

${ }^{2}$ Department of Meteorology and Oceanography, Andhra University, Visakhapatanam, India

Email: raovtz@yahoo.com.br

How to cite this paper: Rao, V.B., Franchito, S.H., Gerólamo, R.O.P., Giarolla, E., Ramakrishna, S.S.V.S., Rao, B.R.S. and Naidu, C.V. (2016) Himalayan Warming and Climate Change in India. American Journal of Climate Change, 5, 558-574.

http://dx.doi.org/10.4236/ajcc.2016.54038

Received: November 17, 2016

Accepted: November 25, 2016

Published: November 28, 2016

Copyright $\odot 2016$ by authors and Scientific Research Publishing Inc. This work is licensed under the Creative Commons Attribution International License (CC BY 4.0).

http://creativecommons.org/licenses/by/4.0/

\begin{abstract}
Recent studies showed that the Himalayan glaciers are reducing alarmingly. This is attributed to global warming. Since the melt water of Himalayan glaciers and snow is the principal source of water for several rivers, a decrease of this source is a calamity for the large fraction of global population living in nearby regions such as India. In Asia for the $60 \%$ global population only $36 \%$ of global water is available. Any further decrease of this vital necessity makes the very existence of billions of people doubtful. Here we show, using both observations and one IPCC-AR4 model with high horizontal resolution, that the Himalayan region in fact underwent a maximum warming of $2.5^{\circ} \mathrm{C}$ from 1950 to 1999 and would reach the highest temperature rise of $9^{\circ} \mathrm{C}$ in 2100. Temperature and rainfall variations determine a simple climate classification proposed by Köppen. We show changes that occur in climate and biosphere using this classification. Also we discussed the impact of warming and resulting changes in Köppen climates on the floods and malaria in India.
\end{abstract}

\section{Keywords}

Himalayan Glaciers, Global Warming, Floods in India, Malaria in India, IPCC AR4 Model, Köppen Climates

\section{Introduction}

An inevitable consequence of most of the human activity such as industrial revolution is the burning of fossil fuels, a process which oxidizes carbon into carbon dioxide $\left(\mathrm{CO}_{2}\right)$ leading to increase of this greenhouse gas. Increase of $\mathrm{CO}_{2}$ enhances the trapping of heat radiated from earth resulting in higher air temperatures, or to global warming. It is well known that in nearby regions response to global warming is not uniform and varies from one place to other. Warming over the mountains such as Andes and Hima- 
layas reduces the glaciers which are the main source of water for the populations that depend on melt water [1] [2] [3] [4]. [2] [3] [4] showed that Himalayan glaciers are retreating alarmingly. These glaciers with warming release melt water that feeds the tributaries of several rivers such as Ganges, Indus, Brahmaputra, Mekarg, Yang-Tse, Irandi and others with glacial melt contributing up to about $45 \%$ of the total river flow [5].

Presently in Asia for the $60 \%$ of global population only $36 \%$ of global water is available [6]. Thus, this vital necessity for human, animal and plant life is already scarce in this part of the globe. Any further decrease makes the very existence of life doubtful. Thus the mass loss of Himalayan glaciers due to warming is of great societal concern.

A simple and sure way of verifying the global warming is to check for temperature rise. There are some studies suggesting warming over the Himalayas [7] [8] [9] [10]. Over Tibetan Plateau, [7] noted a warming of $0.16^{\circ} \mathrm{C}$ per decade and using 7 instrumental records. [8] suggested that the western Himalayas (Karakoram glaciers) are cooling associated with thickening and expansion of some glaciers in contrast to decay and retreat of eastern Himalayas. However, in a recent study [11] found that Naimona'nyi glacier in the Himalaya $\left(30^{\circ} 27.06^{\prime} \mathrm{N}, 81^{\circ} 91.94^{\prime} \mathrm{E}\right)$ not far from Karakoram glaciers is losing mass probably due to warming. [12] noted that the long term trends in the maximum, minimum and mean temperatures over northwest Himalaya during the twentieth century showed significant rise in the air temperature with winter warming occurring at a faster rate. [9] presented observational evidence to show that the surface air temperature on the eastern Himalayas or Tibetan Plateau has increased by about $1.8^{\circ} \mathrm{C}$ over the period 1960-2007. [10], using the microwave satellite measurements, showed that the tropospheric temperature over western Himalayas has increased $2.7^{\circ} \mathrm{C}$ in the period 1979-2007 during the premonsoon season (March, April and May).

In view of the strong societal implications of the Himalayan glacier mass loss due to increase of temperature, it is of crucial importance to know how the temperature varies in a warming scenario. This can only be provided by one of the latest generation of global climate models with some degree of reliability. In the present study we use a high resolution [13] Ocean Coupled Atmospheric General Circulation Model (GCM) to estimate the temperature change over the Himalayan regions. Although in the beginning different GCMs gave different estimates of temperature change for a given concentration of $\mathrm{CO}_{2}$, recently they seem to have become more reliable converging to the same result [14]. Also it was shown that models that have higher fidelity for reproducing the present climate, predict higher values of global warming for doubled $\mathrm{CO}_{2}$ [15].

In a simple climate classification proposed by Köppen, surface air temperature is the principal meteorological element (finer divisions are based on precipitation). Köppen's classification can be effectively used to study biosphere changes [16]. In this paper we investigate the climate change, in particular, temperature variation and changes in biosphere in India and surrounding regions. Also we analyze the impact of these changes on floods in rivers fed by Himalayan snow and glacier melt and a tropical disease, Malaria.

\section{Data Sources}

Monthly mean surface air temperature and rainfall for the period 1950-1999 were ob- 
tained from [17]. The horizontal resolution is $0.5^{\circ}$ latitude and longitude. For the model data, we used MIHR data [13]. The model results are for A1B Scenario (IPCC). The A1B scenario assumes significant innovations in energy technologies, which improve energy efficiency and reduce the cost of energy supply. Such improvements occur across the board and neither favor, nor penalize, particular groups of technologies. A1B scenario assumes, in particular, drastic reductions in power-generation cost, through the use of solar, wind and other modern renewable energies, and significant progress in gas exploration, production, and transport. This results in a balanced mix of technologies and supply sources with technology improvements and resource assumptions such that no single source of energy is overly dominant.

Table 1 gives the horizontal resolution of all the 21 models used in [13] IPCC (2007). It can be seen that the MIHR model has the highest horizontal resolution (1.125 latitude and longitude) compared to 20 others models of IPCC. Since the horizontal resolution of observed data source [17] is $0.5^{\circ}$ latitude and longitude, we selected MIHR model data which has the best horizontal resolution. We used the Köppen classification for the biome distributions and bioclimatic classification. This simple climatic classification has advantages over complex dynamic vegetation models in that it is empirical and easy to apply for the prediction of future climates based mainly on temperature and rainfall. Here we used the Köppen vegetation types as given in Table 1 of [16] reproduced here in Table 2.

Table 1. Horizontal resolution of 21 models.

\begin{tabular}{cc}
\hline MODEL & RESOLUTION LAT $\times$ LON \\
\hline BCM2 (Norway) & $2.8^{\circ} \times 2.8^{\circ}$ \\
CGMR (Canada) & $2.8^{\circ} \times 2.8^{\circ}$ \\
CNCM3 (France) & $2.8^{\circ} \times 2.8^{\circ}$ \\
CSMK3-CSIRO (Australia) & $1.875^{\circ} \times 1.875^{\circ}$ \\
ECHOG (Germany/Korea) & $2.5^{\circ} \times 3.75^{\circ}$ \\
FGOALS (China) & $2^{\circ} \times 2.5^{\circ}$ \\
GFCM2.0 (USA) & $2^{\circ} \times 2.5^{\circ}$ \\
GFCM2.1 (USA) & $3^{\circ} \times 4^{\circ}$ \\
GIAOM (USA) & $4^{\circ} \times 5^{\circ}$ \\
GIEH-NASA (USA) & $4^{\circ} \times 5^{\circ}$ \\
GIER-NASA (USA) & $2.5^{\circ} \times 3.75^{\circ}$ \\
HADCM3 (UK) & $1.25^{\circ} \times 1.875^{\circ}$ \\
HADGEM (UK) & $4^{\circ} \times 5^{\circ}$ \\
INCM3 (Russia) & $2.5^{\circ} \times 3.75^{\circ}$ \\
IPCM4 (France) & $1.125^{\circ} \times 1.125^{\circ}$ \\
MIHR (Japan) & $2.8^{\circ} \times 2.8^{\circ}$ \\
MIMR (Japan) & $1.875^{\circ} \times 1.875^{\circ}$ \\
MPEH5 (Germany) & $2.8^{\circ} \times 2.8^{\circ}$ \\
MRCGCM (Japan) & $1.4^{\circ} \times 1.4^{\circ}$ \\
NCCCSM (USA) & $2.8^{\circ} \times 2.8^{\circ}$ \\
NCPCM (USA) &
\end{tabular}


Table 2. Köppen vegetation types, reproduced from Gnanadesikan and Stowfer (2006).

\begin{tabular}{|c|c|c|}
\hline Type & Name (nominal vegetation type) & Criteria \\
\hline 2. Am & Troipical moist (Tropical evergreen rainforest) & $\operatorname{Tmim}>18^{\circ} \mathrm{C}$, not BS or BW, $6>$ Pmim $>(250-$ Pyear $) / 25$ \\
\hline 3. Aw & Troipical dry (Savanna/Woodland) & Tmim $>18^{\circ} \mathrm{C}$, not BS or BW, $6(250-$ Pyear $) / 25>$ Pmim \\
\hline 4. BS & Semiarid (Bush or grassland) & $\begin{array}{c}2 \text { (Tave }+ \text { Poff })>\text { Pyear }>\text { (Tave }+ \text { Poff) Poff }=0,>30 \% \text { of rain in winter } \\
\text { Poff }=7 \text {, no wet season Poff }=14,>30 \% \text { of rain in summer }\end{array}$ \\
\hline 5. BW & Desert (waste to cactus/seasonal vegetation) & (Tave + Poff $)>$ Pyear \\
\hline 6. Cs & Temeprate winter wet (Evergreen broadleaf forest) & $\begin{array}{c}18^{\circ} \mathrm{C}>\mathrm{Tmim}>-3^{\circ} \mathrm{C} \text {, not } \mathrm{BS} \text { or } \mathrm{BW} \\
\text { Pmax }>\text { \#3 Pmim winter max., summer mim. }\end{array}$ \\
\hline 7. Cfa & Hot temperate moist (Broadleaf forest) & $18^{\circ} \mathrm{C}>\operatorname{Tmim}>-3^{\circ} \mathrm{C}$, not BS or BW, Not Cs or Cw, Tmax $>22^{\circ} \mathrm{C}$ \\
\hline 9. $\mathrm{Cfc}$ & Cold temperate moist (Needle-tree forest) & $\begin{array}{c}18^{\circ} \mathrm{C}>\mathrm{Tmim}>-3^{\circ} \mathrm{C} \text {, not } \mathrm{BS} \text { or } \mathrm{BW} \text {, Not } \mathrm{Cs} \text { or } \mathrm{Cw}, \mathrm{Tmax}<22^{\circ} \mathrm{C} \\
\text { Less than } 4 \text { months warmer than } 10^{\circ} \mathrm{C}\end{array}$ \\
\hline 10. $\mathrm{Cw}$ & Temperate summer wet (evergreen forest) & $\begin{array}{c}18^{\circ} \mathrm{C}>\mathrm{Tmim}>-3^{\circ} \mathrm{C} \text {, not } \mathrm{BS} \text { or } \mathrm{BW} \\
\text { Pmax }>10 \text { Pmim, summer max., winter mim }\end{array}$ \\
\hline 11. Dab & Colder winters//warmer summers (Deciduous forest) & $\operatorname{Tmax}>10^{\circ} \mathrm{C},-3^{\circ} \mathrm{C}>\mathrm{Tmim}$, not $\mathrm{BS}$ or $\mathrm{BW}, 4+$ months warmer than $10^{\circ} \mathrm{C}$ \\
\hline 12. Dc & Cold winters/cool summers (Evergreen forest) & $-3^{\circ} \mathrm{C}>\mathrm{Tmim}$, not $\mathrm{BS}$ or BW, 4 -months warmer than $10^{\circ} \mathrm{C}$ \\
\hline 13. Et & Tundra (Tundra/dwarf trees, mosses) & $10^{\circ} \mathrm{C}>\mathrm{Tmax}>0^{\circ} \mathrm{C}, \mathrm{Tmim}<-3^{\circ} \mathrm{C}$ \\
\hline $14, \mathrm{Ef}$ & Polar desert (Pernanent ice or rock, litle plant life) & $\operatorname{Tmax}<0^{\circ} \mathrm{C}$ \\
\hline
\end{tabular}

\section{Results and Discussion}

To increase the confidence on regional climate prediction, particularly for a future scenario, validation is necessary. We now make an attempt to validate the model temperature with observed temperature. Figure 1(a) and Figure 1(b) show the temperature in the model and observations respectively for the period 1961-1990. The pattern correlation between the model and observed temperature is 0.92 . The total number of grid points used for the calculation of pattern correlation is 3286 and the area used is the same as shown in Figure 1.

The pattern correlation of 0.92 is significant at $99.9 \%$ level by a two sided Student " $\mathrm{t}$ " test. The model seems to have reproduced many of the observed features such as rapid temperature decrease to the north from the foothills of Himalayas, as expected because of the strong height decrease. But the model results show $-15^{\circ} \mathrm{C}$ as the lowest temperature while observations show $-10^{\circ} \mathrm{C}$. This may be due to the lack of surface stations in this region. Also a careful examination of $25^{\circ} \mathrm{C}$ isotherm shows differences in the northwest of India and Pakistan. The variations in surface temperature further west show more variability in the observations. Over peninsular India also there are some differences over the Western Ghats. Thus the model seems to capture at least the basic temperature characteristics except for some finer details. 


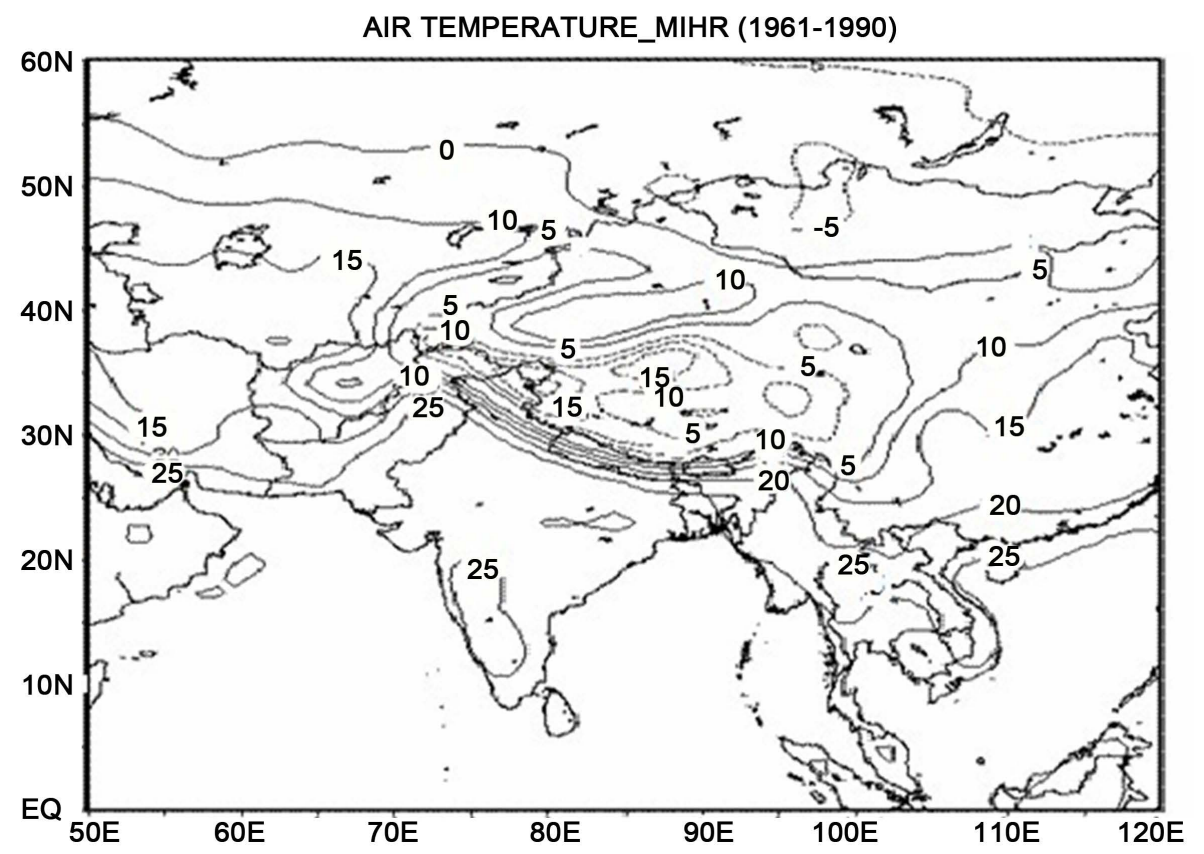

(a)

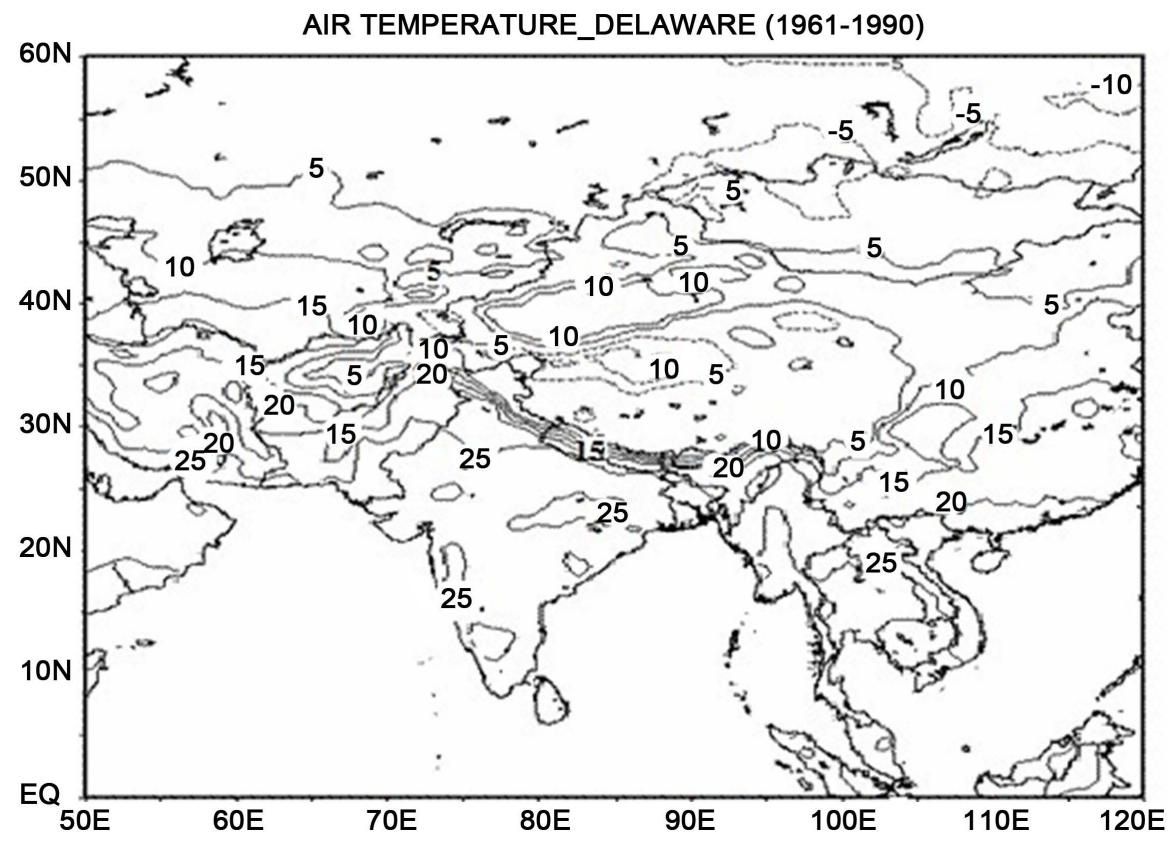

(b)

Figure 1. (a) Surface air temperature from MIHR model, mean for the period 1961-1990, (b) Same as (a) but for the Delaware data (Willmott and Matsuura, 2001).

Figure 2(a) presents the air temperature difference between the periods 1975-1999 and 1950-1974 calculated from observations. This clearly shows an increase of temperature in recent years over the Himalaya with a maximum of around $2.5^{\circ} \mathrm{C}$. The rise is spread over a wide area. 


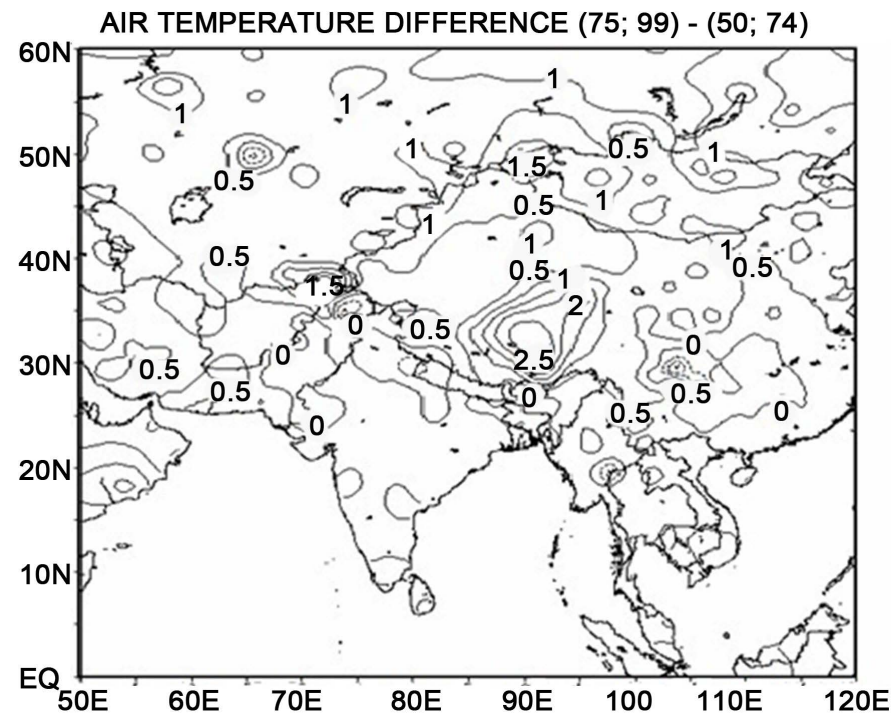

(a)

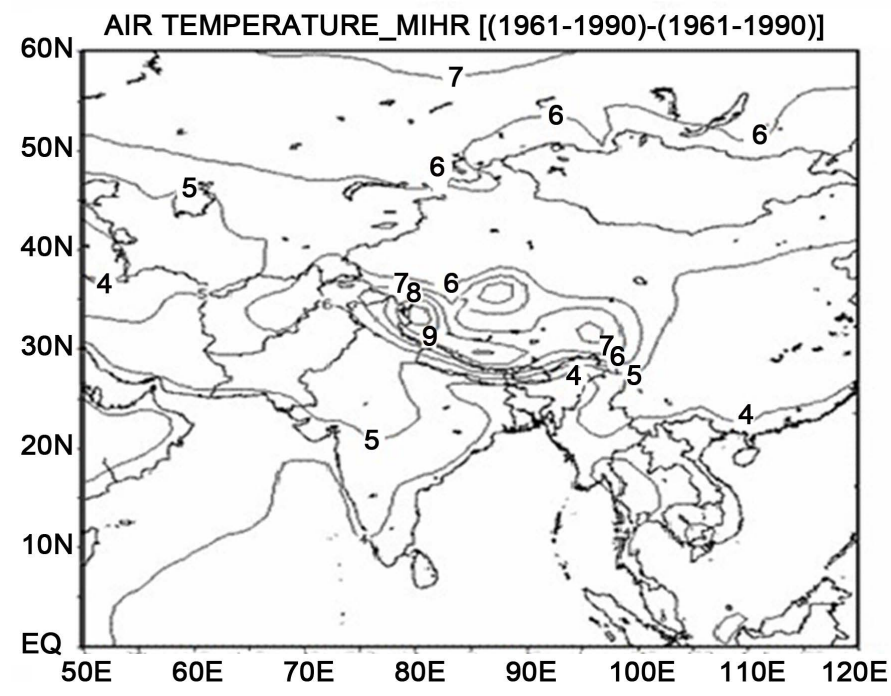

(b)

Figure 2. (a) Surface air temperature difference between the periods 1975-1999 and 1950-1974 from observations; (b) Same as (a) but for the period 2070-2099 and 1961-1990. Model data.

Figure 2(b) illustrates the temperature change between the periods 2070-2099 and 1961-1990 as obtained from MIHR. As mentioned earlier, this model shows a pattern correlation of 0.92 with the observed temperature. Thus it seems to be reliable to predict future temperature rise for A1B scenario. Further the systematic errors are cancelled in the difference between the two periods. Over the entire Indian subcontinent and surrounding regions there will be a substantial rise of temperature by the year 2100 with a maximum of about $9^{\circ} \mathrm{C}$ in the Himalayan region. Even in a less drastic scenario (B1), the maximum rise of temperature over the Himalayan region (figure not shown) is around $6.5^{\circ} \mathrm{C}$. Over peninsular India (Figure $2(\mathrm{~b})$ ) there is a rise of $4^{\circ} \mathrm{C}$ in the south, increasing to $5^{\circ} \mathrm{C}$ over the northwestern India. The increase of temperature over the 
Himalayas in Figure 2(a) seems to be the cause of the decrease of the glaciers as mentioned earlier. This together with the future increase of temperature is bound to reduce the water resources. In recent years during the summer monsoon intense rainfall events have increased and moderate rainfall events decreased [18]. The increase of intense events increases the surface runoff and less water is retained in the soil. Thus, the overall picture of water availability is gloomy both for human consumption and food production.

Figure 3(a) and Figure 3(b) show, respectively, the surface air temperature trend ( ${ }^{\circ} \mathrm{C} /$ year) in the observations for the period 1950-1999 and in the model for the period

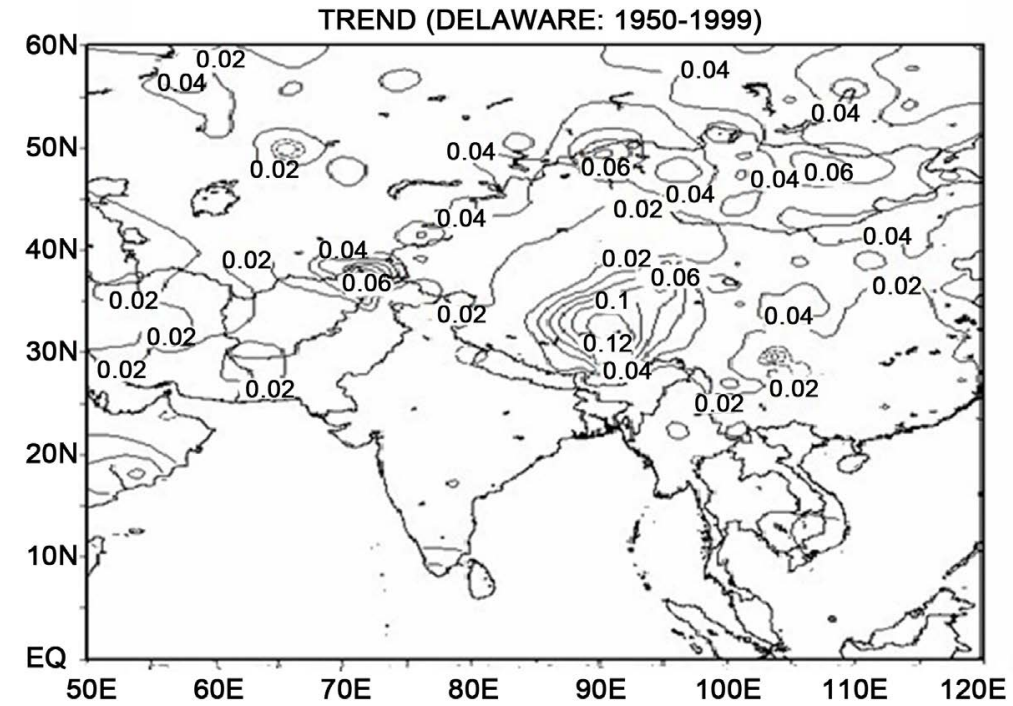

(a)

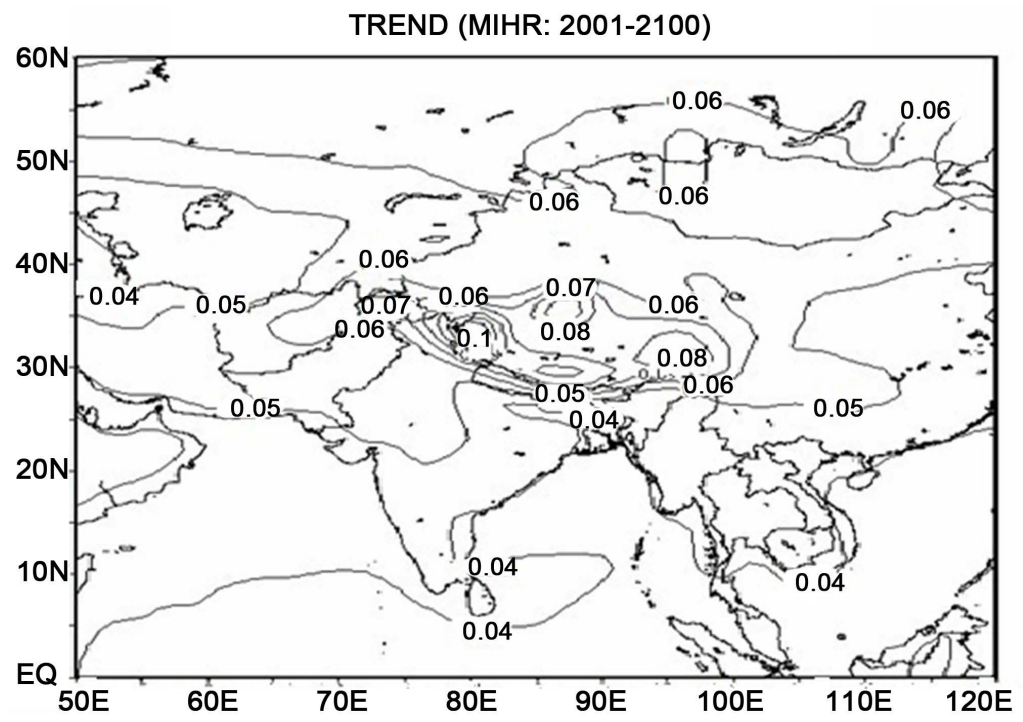

(b)

Figure 3. (a) Temperature tendency $\left({ }^{\circ} \mathrm{C} /\right.$ year) in observations for the period, 1950-1999; (b) same as (a) but for the model data, 2010-2100. 
2001-2100. In Figure 3(a) we can see a clear increasing trend with a maximum of a $0.12^{\circ} \mathrm{C}$ per year (significant at $99 \%$ level by a two sided Student " $t$ " test) over the Himalayas. In the model results for the future (Figure 3(b)) there is an increasing trend (significant at $99 \%$ level by a two sided Student " $t$ " test) over Himalayas with maximum of around $0.1^{\circ} \mathrm{C}$ per year (significant at $99 \%$ level by a two sided Student " $t$ " test).

Figure 4(a) shows the monthly temperature variation for the period 2005-2100 in the model averaged over the area $30^{\circ} \mathrm{N}-35^{\circ} \mathrm{N}, 80^{\circ} \mathrm{E}-90^{\circ} \mathrm{E}$. This area approximately

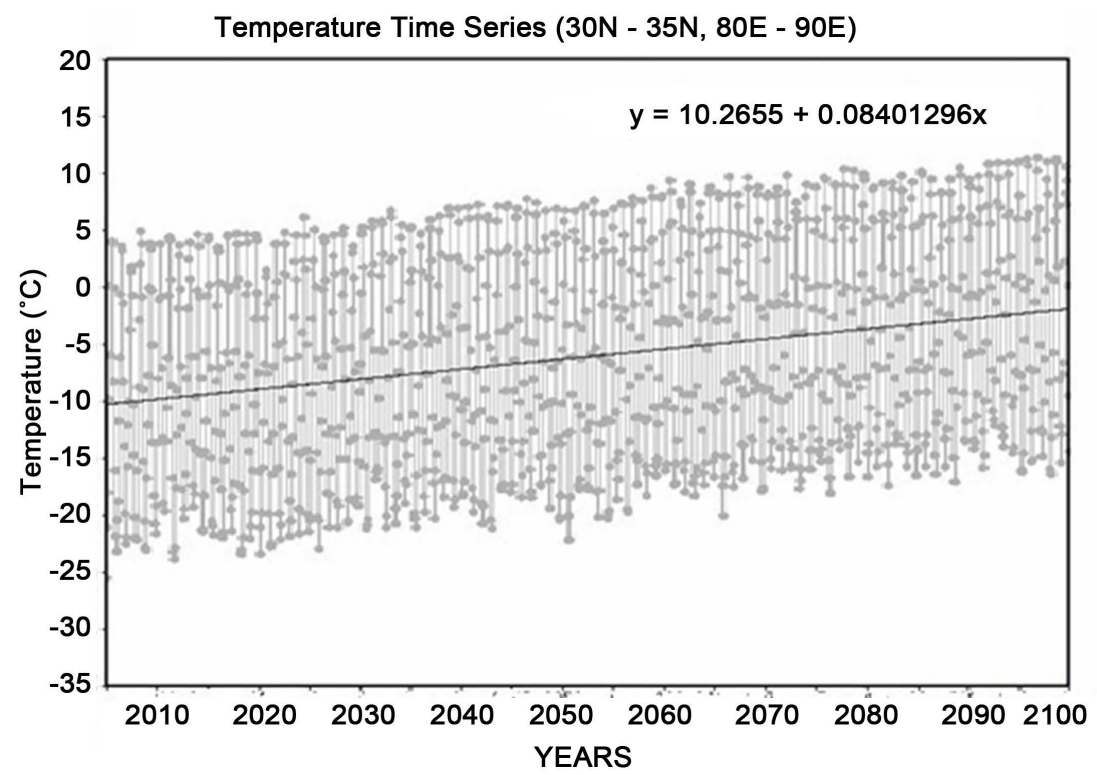

(a)

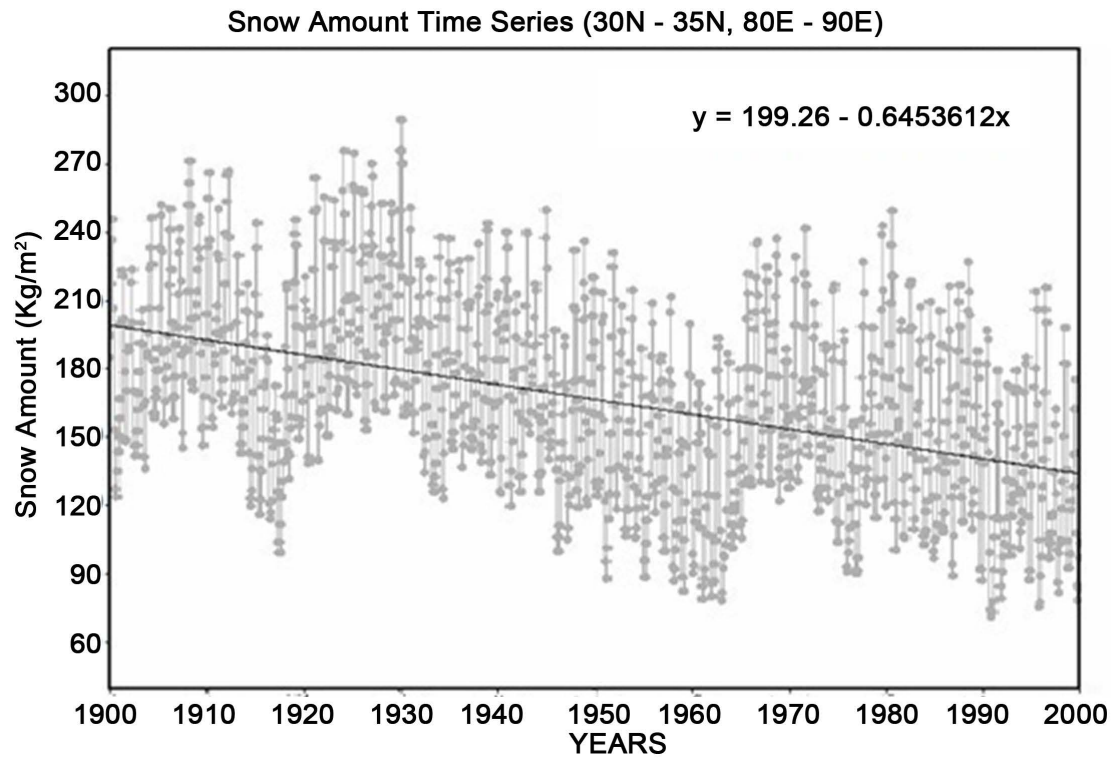

(b)

Figure 4. (a) Temperature variations $\left({ }^{\circ} \mathrm{C}\right.$ ) in the model data for the area, $30^{\circ} \mathrm{N}-35^{\circ} \mathrm{N}$ and $80^{\circ} \mathrm{E}$ $90^{\circ} \mathrm{E}$; (b) corresponding variation of snow amount $\left(\mathrm{Kg} \cdot \mathrm{m}^{-2}\right)$. 
covers the entire Himalayas. A clear rising trend of $0.084^{\circ} \mathrm{C}$ per year (significant at $99 \%$ level by a two sided " $\mathrm{t}$ " test) is seen. The corresponding snow variation amount (kg $\mathrm{m}^{-2}$ ) for this area is shown in Figure 4(b). A clear decreasing trend of $0.645 \mathrm{~kg} \cdot \mathrm{m}^{-2}$ (significant at $99 \%$ level by a two sided " $\mathrm{t}$ " test) is seen. However, the quantitative value of the rate of snow decrease is subjected to model uncertainties and errors (see the comment in the conclusion section).

In the model the amount of snow and ice is calculated as a function of increase of temperature. This increase of temperature and decrease of snow and ice amount is because of the strong ice and snow-albedo feedback [19]. This feedback is a strong positive feedback mechanism that is as the temperature increases the amount of snow and ice decreases, decreasing the albedo, which in turn favors higher absorption of solar radiation leading to further increase of temperature. This seems to be the mechanism which is responsible for the increase of temperature seen in Figure 3(a) and Figure 3(b) over the Himalayas. The initial increase of temperature is probably due to the increase of greenhouse gases. This small initial increase of temperature has a drastic effect over the Himalayas reducing the snow and ice and because of the snow and ice albedo feedback mechanism, the temperature increases more sharply over the Himalayan region than in other regions.

\subsection{Floods in India}

In India northern rivers are snow fed and southern rivers are monsoon fed. India is the most flood-affected nation in the world after Bangladesh. It accounts for one fifth (1/5) of global deaths due to floods and on an average thirty million people are evacuated every year. These flood events in India are increasing (see Figure 5) [20].

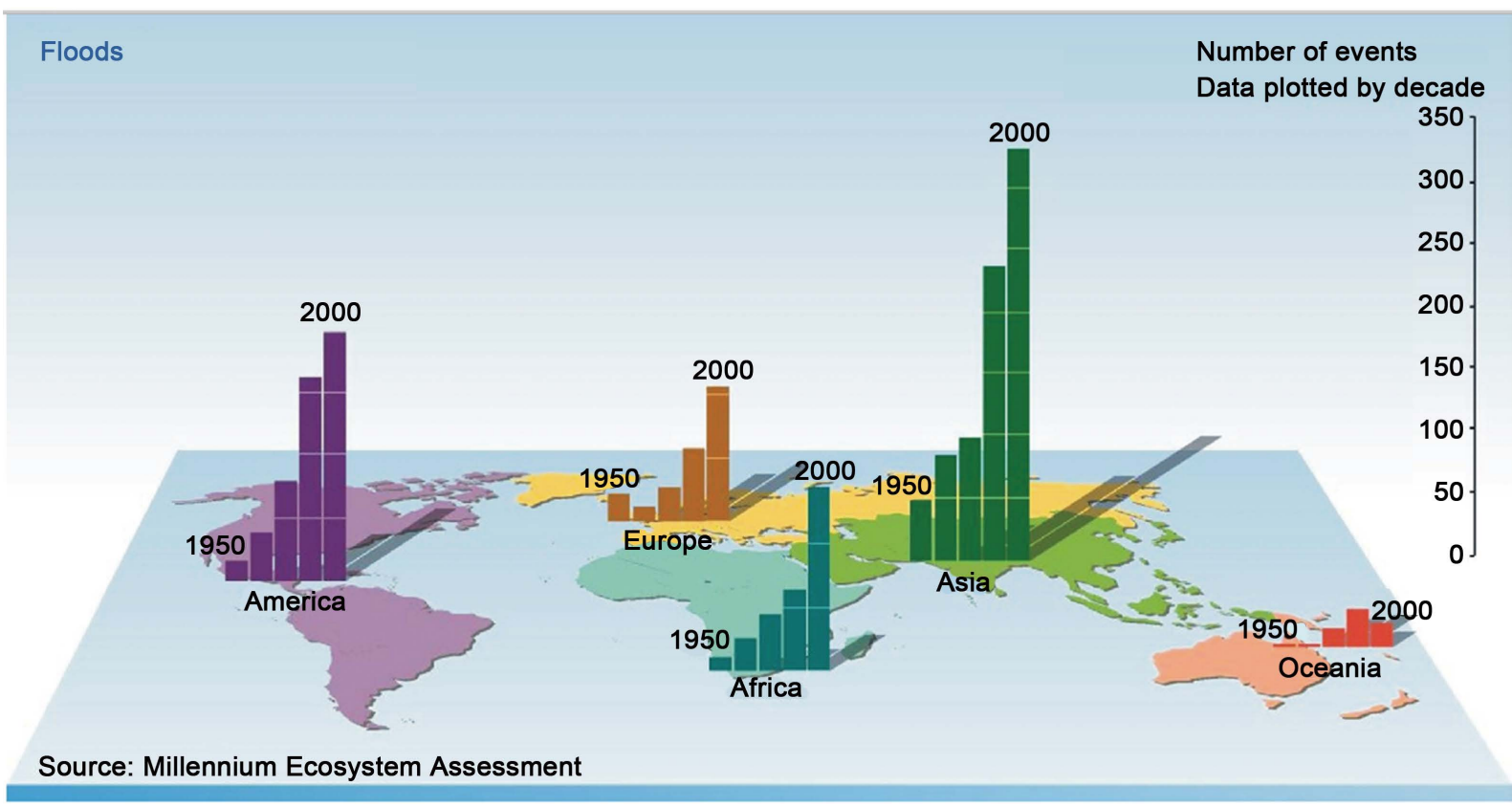

Figure 5. Number of flood events by continent and decade since 1950. 
Geographic regions where water supply is dominated by melting snow and ice are predicted to suffer severe reduction in water volume as a result of warming [21]. Strong negative impacts such as precipitation variability, seasonal shifts in water supply and increased flood risk will offset benefits incurred by short-term increases in runoff from glacier melts [22], such as Himalayan glaciers which form the headwaters for the Indus, Ganges, Brahmaputra and Kosi rivers. The increased warming over the Himalayan glaciers has left many glacier lakes. Rapid accumulation of water in these lakes due to warming might lead to sudden breaching of unstable dams behind which they are formed leading to floods.

Glacial Lake Outburst Floods (GLOFs) can occur because of the resultant discharge of large amounts of water and sediment. [23] noted that in the past 5 decades at least one GLOF event occurred between 3 to 10 years in this region. Bhutiyani et al. 2008 [24] noted a significant increase of high-magnitude flood events in the northwestern Himalayas. Liu et al. 2009 [25] noted that over the Tibetan Plateau annual runoff increased by $20 \%$ during the past decade and they also noted lake growth.

The ice and snow albedo feedback increases temperature as seen in Figure 2(a), Figure 3(a) and Figure 4(a). The states of Bihar and Assam in India are worst hit by floods in the summer of 2008 and millions of people were affected. The Kosi river of Bihar and the Brahmaputra river of Assam are in spate partly due to the heavy monsoon rains and partly due to the snowmelt because of the Himalayan warming. In the Arun-Kosi river basins there are several glaciers in Tibet and several glacier lakes, which formed due to the snowmelt because of Himalayan warming. The increase of volume of water caused floods. The Brahmaputra River has its origin in the Himalayan glaciers and thus is directly affected by glacier melting due to Himalayan warming. [26] studied the floods in Brahmaputra river basin in India. They noted that floods in this river start from June, which probably may partly be due to the melt waters from Himalayan glaciers. They found that in the Brahmaputra River during the period 1987-1998 at 6 gauges sites a large number of floods occurred.

Although initially ice and snow melt leads to swelling of rivers fed by the melt waters, later the decrease in volume of water leading to scarcity of this vital source is bound to happen.

\subsection{Changes in Köppen Climates}

Figure 6(a) shows the real-word distribution of the Köppen climates as obtained from the Delaware temperature and rainfall data [17] for the period 1975-1999. The 14 Köppen climate types and vegetation types are the same as given in an earlier study [16] and Table 2 gives these 14 types. In the peninsular India, a thin band of Am (Tropical moist, evergreen rain forest) climate is seen on the eastern side of Western Ghats extending to south including Sri Lanka. Further, to the east of Western Ghats, Aw (Tropical dry, savanna/woodland) type climate changing again to Am climate further east is seen. A small region of Aw climate is seen over northern Andhra Pradesh and Orissa states, North India and Nepal experience $\mathrm{Cw}$ (Temperate summer wet, evergreen 


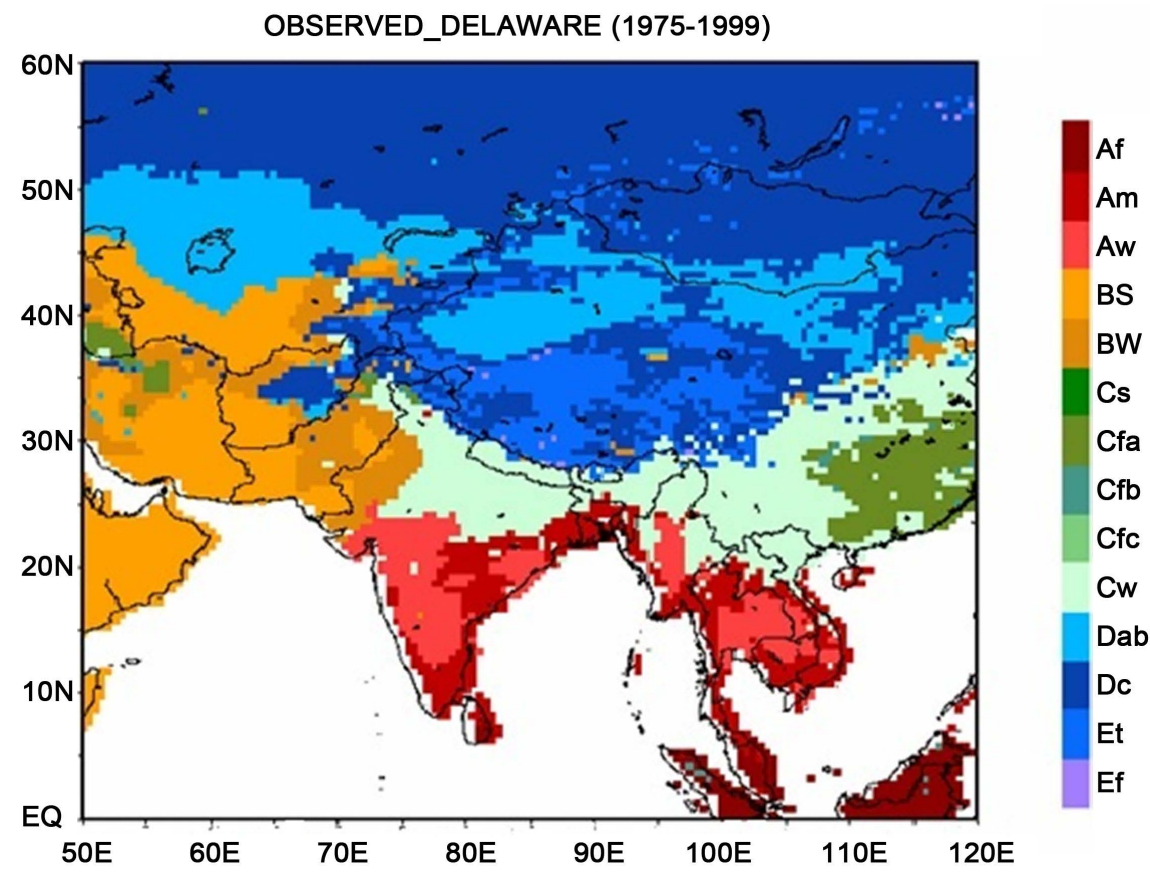

(a)

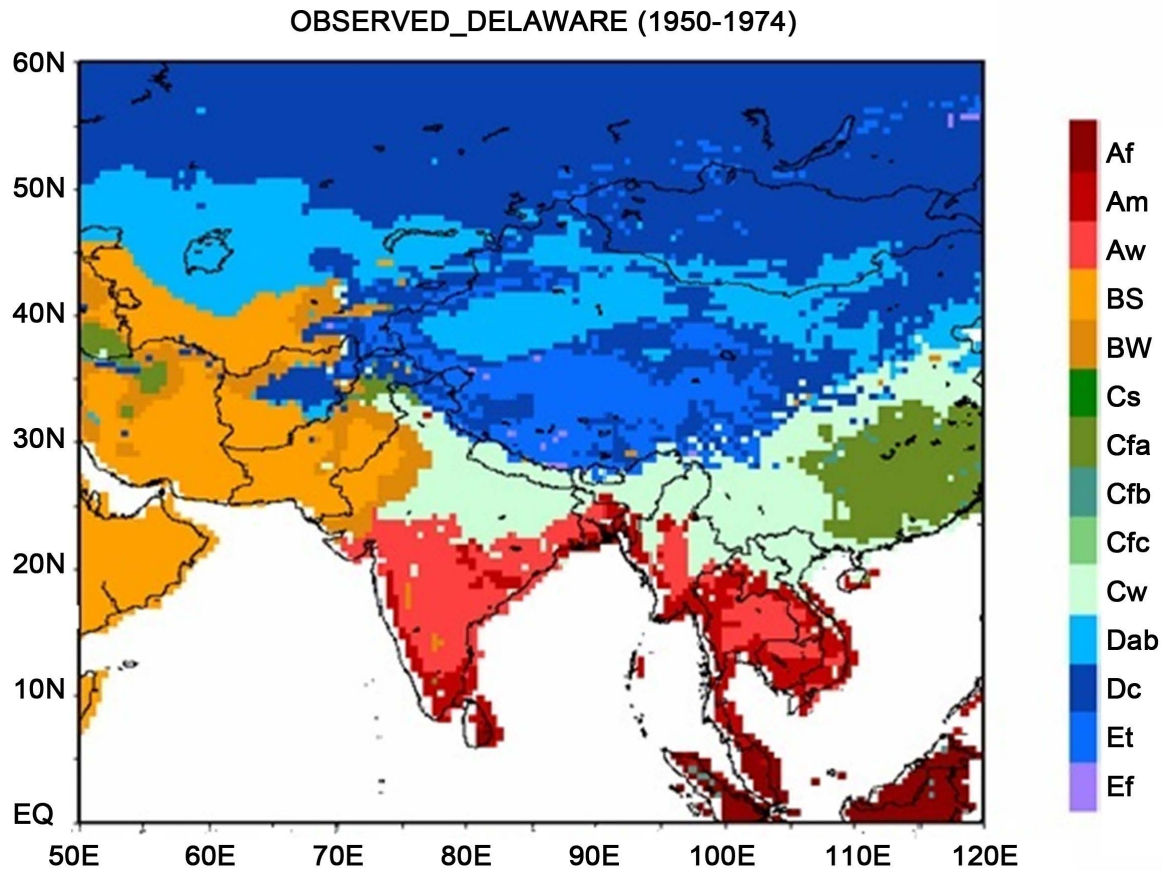

(b)

Figure 6. (a) Observed Köppen climates for the period 1975-1999; (b) Same as (a) but for the period 1950-1974.

forest) type of climate. This type of climate extends over a large region including China. Eastern most China, however, experiences Cfa (Hot temperate moist, broad-leaf forest) climate. Over Myanmar and southeast Asia, Am and Aw climates are seen. Further 
south over Thailand, Malaysia and Indonesia, Af (Tropical wet, evergreen rainforest) climate is seen.

In the northwestern India and further west, dry climates Bs (Semiarid, bush to grassland) and $\mathrm{Bw}$ (Desert, waste to cactus/seasonal vegetation) are noted. Further north, cold climates, Et (Tundra, dwarf trees, mosses), Dc (cold winters/cool summers, evergreen forest) and Dab (Cold winters/warm summers, deciduous forest) climates are seen.

A comparison of observed climates for the earlier period (1950-1974) (Figure 6(b)) shows that over the peninsular India Am climates occupied a larger area in recent years (1975-1999). Over northwestern India, the desert climate Bw extended in recent years. A careful examination of Figure 6(b) reveals that over Himalaya some regions were changed from Et to Dc climate, probably because of the increase of temperature, as seen in Figure 2(a). Over eastern China, Cfa climate area has reduced in recent years. This seems to be due to the decrease of temperature, as seen in Figure 2(a).

The corresponding model Köppen climates and vegetation types of MIHR are shown in Figure 7(a). The overall climates and vegetation types as observed, such as Am climate of southern India and Sri Lanka, Cw climate in the north and dry climates, Bs and $\mathrm{Bw}$ in the northwest, seem to be reasonably well simulated. However, there are clear differences. In the peninsular India, observed climate shows a band of Am (monsoon climate) on the eastern side of the Western Ghats changing to Aw to the northeast, while in the model this change was not simulated except for a small part in the northwest. Part of this deficiency in the model could be due to the differences in the horizontal resolution, observations are on a $0.5^{\circ} \times 0.5^{\circ}$ latitude and longitude grid while the model is $1.125^{\circ} \times 1.125^{\circ}$ latitude and longitude grid. Cfa climate over eastern China and Am and Af climates over southeast Asia and Indonesia are reasonably well simulated, except for a small band of Aw climate observed over Myanmar. Over western Iran the model wrongly shows the $\mathrm{Cw}$ climate, which is not seen in observations.

In the simulation of future climate for years (2070-2099) (Figure 7(b)), the results suggest that a large area of $\mathrm{Cw}$ climate in the northeastern India and Bangladesh will be reduced and replaced by Am climate. Over northwestern India, Aw climate will be increased. An examination of temperature and rainfall showed that these changes are mainly due to increase of temperature and slight increase or decrease of rainfall. Over southeast Asia, also a part of the $\mathrm{Cw}$ climate is replaced by Am climate. Over eastern China, Cfa climate is likely to be replaced by $\mathrm{Cw}$ climate over a large area with Bs and Bw appearing over western China. Over northern China, Mongolia and eastern Russia, there is a change of Et climate to Dc and Dc climate to Dab climate. This is mainly due to the increase of temperature, as seen in Figure 2(b).

\subsection{Malaria in India}

Warmer and more humid climates favor increase of tropical diseases such as Malaria. Earlier we noted that in recent years (Figure 6(a) and Figure 6(b)) a warmer and humid climate Am occupied a larger area over peninsular India. 


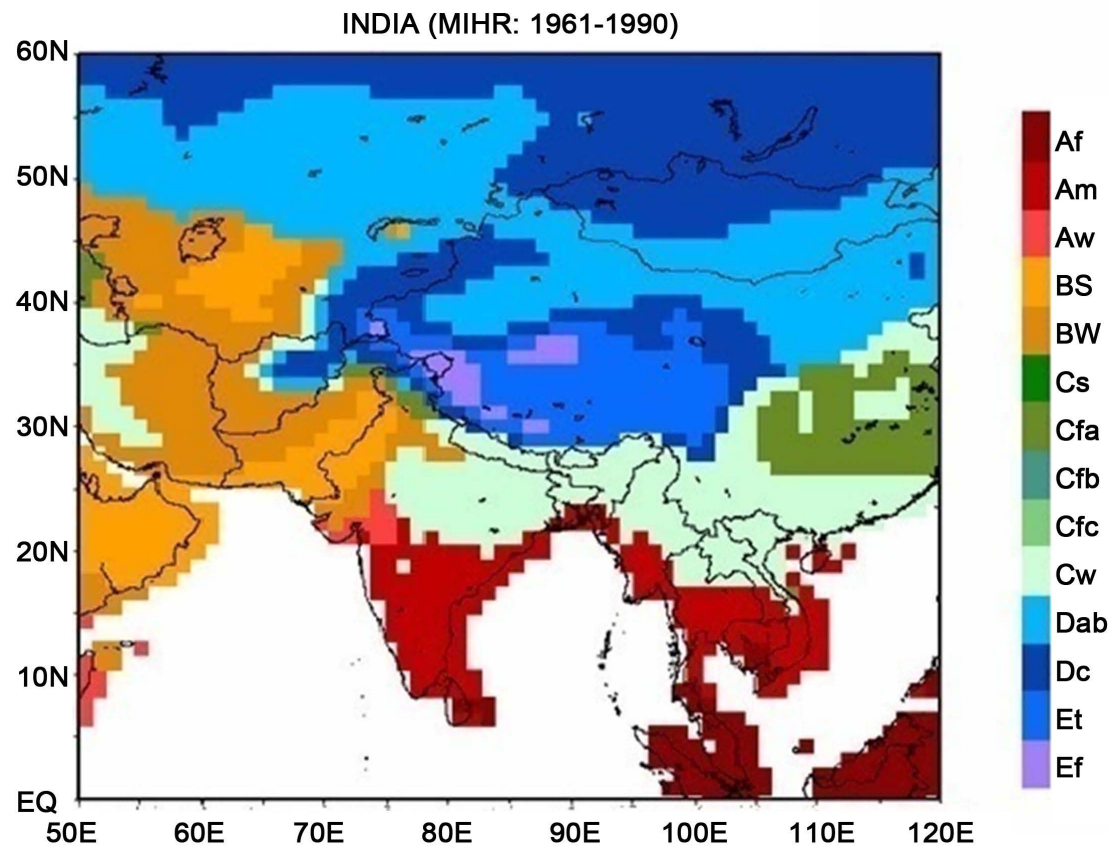

(a)

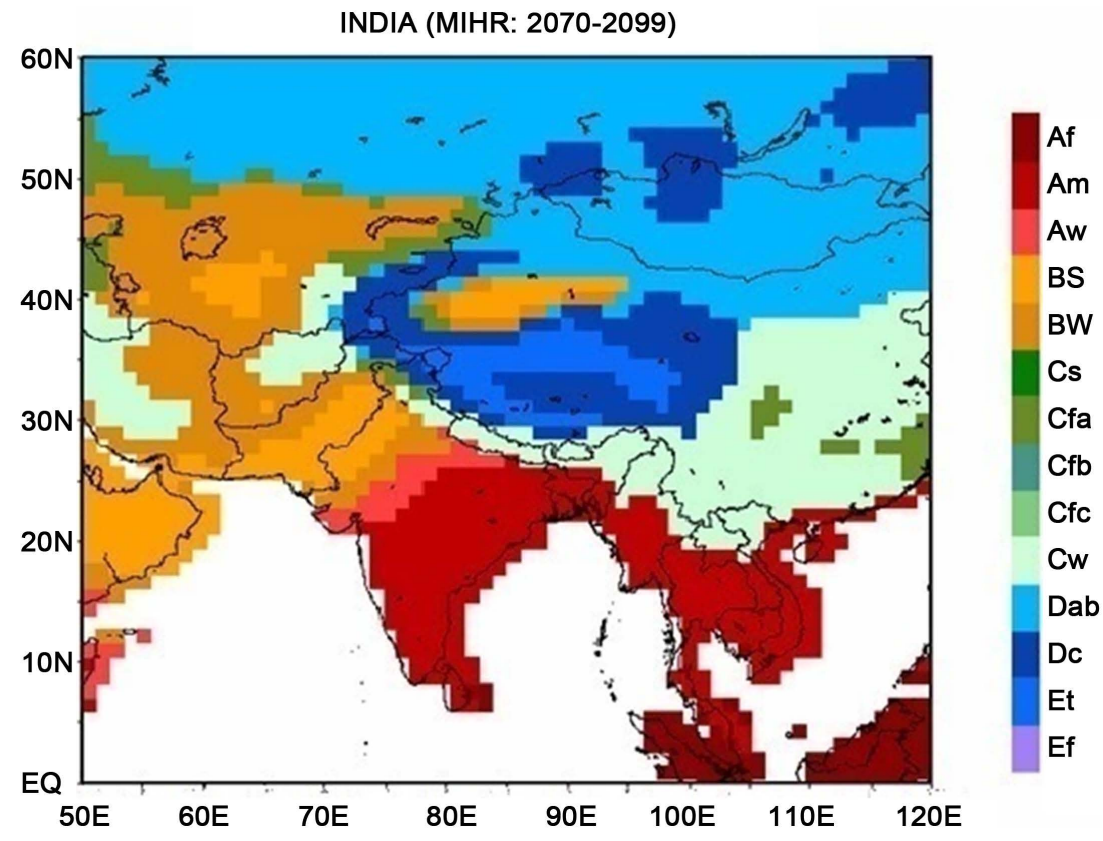

(b)

Figure 7. (a) Model Köppen climates for the period 1961-1990, (b) Same as (a) but for the period 2070-2090.

India contributes about 70\% of Malaria cases in the southeast Asian Region of World Health Organization (WHO) [27]. [27] noted that annually India reports about two million cases and 1000 deaths attributable to malaria and there is an increasing trend in the proportion of Plasmodium falciparum (PF) as the agent (see Figure 1 of [27]). [27] 
also mentioned that now $45 \%$ of all reported cases are due to PF.

A careful examination of our Figure 6(a) and Figure 6(b) shows that from 1975 onwards Am (tropical moist) climates replaced Aw (tropical dry) climates over a larger region in the peninsular India, particularly on the eastern side. It is not a coincidence that these are in fact the regions which contributed to a large part of Malaria in India (See Figure 3 and Figure 4 of [28]).

In future climate (2070-2099) our Figure 7(b) shows that a very large area over India will be occupied by Am climate. This shows the imminent danger of the increase of tropical diseases, in particular Malaria. In a recent study, [29] warned that on a global scale the increasing air temperatures are at odds with the decreasing global trends in endimicity and geographic extent of Malaria. However, we suggest here that there can be a connection between the regional climate change and increase of Malaria and the possible relation between the two is worth investigating. Also, some studies [30] suggest the incidence of Malaria is highly sensitive to climate change and the endemic areas increased in some regions.

\section{Conclusions}

Observations suggest that in recent years temperature over Himalaya increased with a maximum of $2.5^{\circ} \mathrm{C}$, leading to the decrease of glaciers. The floods in the northern Indian states of Bihar and Assam in 2008 dislocating millions of people and killing some are at least partially due to the initial swelling of the Kosi and Brahmaputra rivers resulting from the Himalayan glacier melting. In a March 2009 climate change congress at Copenhagen it was mentioned that for many key parameters, such as surface temperature, the climate system is already shifting to the patterns beyond natural variability. Poor nations and communities such as those we studied here are highly vulnerable to even modest changes of climate change. Rapid, sustained and effective mitigation of the hazards such as floods necessitates preparedness based on the knowledge of scientific results. The present study is an attempt in this direction. The future depletion of the Himalayan glaciers leading to the scarcity of drinking water in the rivers fed by the glaciers melt is imminent. Simulation of future climate with a model of high fidelity shows that the Himalayan region might experience an increase of temperature as high as $9^{\circ} \mathrm{C}$ and southern India also warms up with temperature reaching more than $3^{\circ} \mathrm{C}$. These changes together with changes in precipitation lead to substantial changes in Köppen climates and vegetation types. Over northern India, a $\mathrm{Cw}$ climate almost vanishes and will be replaced by much warmer and more humid Am climate. A warmer and humid climate favors the proliferation of tropical diseases such as Malaria, Dengue and others. The increase of the number of deaths due to Malaria in recent years may, at least partially, be attributed to the increase of Am climate in India, noted earlier. Our results have strong societal relevance because of their importance for the preparedness of a large fraction of global population living in India and surrounding areas for the rapid, sustained and effective mitigation of natural hazards such as floods and large occurrences of tropical diseases such as malaria. 
Finally, in conclusion a word of caution should be written. The model projections have limitations because they are based on the lack of correct representation of some complex and still not completely understood processes such as tropical convection. Further, the future AR-4 scenarios assume some social behaviour, which is again uncertain. The results of the present study, however, indicate the imminent danger of adverse climate change assessed with the current state of knowledge on populations in this part of the globe. Obviously, it is always safer and prudent to be prepared for the adverse effects of climate change. If this change will not happen or happens to a lesser degree and less rapidly, the consequences on the populations can be less disastrous, of course, if they are prepared for the change.

\section{References}

[1] Hastenrath, S. and Ames, A. (1995) Recession of Yanamarey Glacier in Cordillera-Banc, Peru, during the $20^{\text {th }}$ Century. Journal of Glaciology, 41, 191-198.

[2] Kulkarni, A.V., Bahuguna, I.M., Rathore, B.P., Singh, S.K., Randhawa, S.S., Sood, R.K. and Dhar, S. (2007) Glacial Retreat in Himalaya Using Indian Remote Sensing Satellite Data. Current Science, 92, 69-74.

[3] Kulkarni, A.V., Rathore, B.P., Mahajan, S. and Mathur, P. (2005) Alarming Retreat of Parbati Glacier, Beas Basin, Himachal Pradesh. Current Science, 88, 1844-1850.

[4] Oerlemans, J. (2005) Extracting Climate Signals from 169 Glacier Records. Science, 308, 675-677. http://dx.doi.org/10.1126/science.1107046

[5] (2003) World Resources Institute.

[6] (2002) UNESCO/International Hydrological Program (IHP). Regional Office of Latin America and the Caribbean.

[7] Liu, X.D. and Chen, B.D. (2000) Climatic Warming in the Tibetan Plateau during Recent Decades. International Journal of Climatology, 20, 1729-1742. http://dx.doi.org/10.1002/1097-0088(20001130)20:14<1729::AID-JOC556>3.0.CO;2-Y

[8] Fowler, H.J. and Archer, D.R. (2006) Conflicting Signals of Climatic Changes in the Upper Indus Basin. Journal of Climate, 19, 4276-4293. http://dx.doi.org/10.1175/JCLI3860.1

[9] Wang, B., Bao, Q., Hoskins, B., Wu, G. and Liu, Y. (2008) Tibetan Plateau Warming and Precipitation Changes in East Asia. Geophysical Research Letters, 35, L14702. http://dx.doi.org/10.1029/2008gl034330

[10] Gautam, R., Hsu, N.C., Lau, K.-M., Tsay, S.-C. and Kafatos, M. (2009) Enhanced PreMonsoon Warming over the Himalayan-Gangetic Region from 1979 to 2007. Geophyisical Research Letters, 36, L07704. http://dx.doi.org/10.1029/2009g1037641

[11] Kehrwald, N.M., Thompson, L.G., Tandong, Y., Mosley-Thompson, E., Schotterer, U., Alfimov, V., Beer, J., Eikenberg, J. and Davis, M.E. (2008) Mass Loss on Himalayan Glacier Endangers Water Resources. Geophysisical Research Letters, 35, L22503. http://dx.doi.org/10.1029/2008gl035556

[12] Bhutiyani, M.R., Kale, V.S. and Pawar, N.J. (2007) Long Term Trends in Maximum, Minimum and Mean Annual Air Temperatures across the Northwestern Himalayas during the Twentieth Century. Climatic Change, 85, 169-177. http://dx.doi.org/10.1007/s10584-006-9196-1

[13] IPCC-Intergovernmental Panel on Climate Change. Climate Change 2007-Fourth Assessment Report of IPCC. $\underline{\text { http://www.ipcc-data.org/ar4/gcm_data.html }}$ 
[14] Simmons, A.J. and Hollingsworth, A. (2002) Some Aspects of the Improvement in Skill of Numerical Weather Prediction. Quarterly Journal of the Royal Meteorological Society, 128, 647-677. http://dx.doi.org/10.1256/003590002321042135

[15] Shukla, J., Delsole, T., Fennessy, M., Kinter, J. and Paolino, D. (2006) Climate Model Fidelity and Projections of Climate Change. Geophysical Research Letters, 33, L07702. http://dx.doi.org/10.1029/2005GL025579

[16] Gnanadesikan, A. and Stowfer, R.J. (2006) Diagnosing Atmosphere-Ocean General Circulation Model Errors Relevant to the Terrestrial Biosphere Using the Köppen Climate Classification. Geophysical Research Letters, 33, L22701. http://dx.doi.org/10.1029/2006GL028098

[17] Willmott, C.J. and Matsuura, K. (2001) Terrestrial Air Temperature and Precipitation: Monthly and Annual Time Series (1950-1999) (Version 1.02). Center for Climatic Research, Department of Geography, University of Delaware.

[18] Goswami, B.N., Venugopal, V., Sengupta, D., Madhusoodanan, M.S. and Xavier, P.K. (2006) Increasing Trend of Extreme Rain Events over India in a Warming Environment. Science, 314, 1442-1445. http://dx.doi.org/10.1126/science.1132027

[19] Schneider, S.H. and Dickinson, R.E. (1974) Climate Modeling. Review of Geophysical Space Physics, 12, 447-493. http://dx.doi.org/10.1029/RG012i003p00447

[20] http://maps.grida.no/go/graphic/number-of-flood-events-by-continent-and-decade-since-1 950

[21] Barnett, T.P., Adam, J.C. and Lettenmaier, D.P. (2005) Potential Impacts of a Warming Climate on Water Availability in Snow-Dominated Regions. Nature, 438, 303-309. http://dx.doi.org/10.1038/nature04141

[22] Cruz, R.V., Harasawa, H., Lal, M., Wu, S., Anokhin, Y., Punsalmaa, B., Honda, Y., Jafari, M., Li, C. and Huu Ninh, N. (2007) Climate Change 2007: Impacts, Adaptation and Vulnerability. Edited by Parry, M.L., et al., Contribution of Working Group II to the Fourth Assessment Report of the Intergovernmental Panel on Climate Change, Cambridge University Press, Cambridge, 469-506.

[23] Bajracharya, S., Mool, P.K. and Shrestha, B.R. (2006) International Symposium on GeoDisasters, Infrastructure Management and Protection of World Heritage Sites. 25-26 November 2006, Nepal Engineering College, Ehime College and National Society for Earthquake Technology, 231-242.

[24] Bhutiyani, M.R., Kale, V.S. and Pawar, N.J. (2008) Changing Stream Flow Patterns in the Rivers of Northwestern Himalaya: Implications of Global Warming in the 20th Century. Current Science, 95, 618-626.

[25] Liu, J., Wang, S., Yu, S., Yang, D. and Zhang, L. (2009) Climate Warming and Growth of High-Elevation Inland Lakes on the Tibetan Plateau. Global and Planetary Change, 67, 209217. http://dx.doi.org/10.1016/j.gloplacha.2009.03.010

[26] Dhar, O.N. and Nandargi, S. (2000) A Study of Floods in the Brahmaputra Basin in India. International Journal of Climatology, 20, 771-781. http://dx.doi.org/10.1002/1097-0088(20000615)20:7<771::AID-JOC518>3.0.CO;2-Z

[27] Dash, A.P., Valecha, N., Anvikar, A.R. and Kumar, A. (2008) Malaria in India: Challenges and Opportunities. Journal of Biosciences, 33, 583-583. http://dx.doi.org/10.1007/s12038-008-0076-x

[28] Kumar, A., Valecha, N., Jain, T. and Dash, A.P. (2007) Burden of Malaria in India: Retrospective and Prospective View. American Journal of Tropical Medicine and Hygiene, 77, 6978. 
[29] Gething, P.W., Smith, D.L., Patil, A.P., Tatem, A.J., Snow, R.W. and Hay, S.I. (2010) Climate Change and the Global Malaria Recession. Nature, 465, 342-094.

http://dx.doi.org/10.1038/nature09098

[30] Martens, W.J.M., Jetten, T.H. and Focks, D.A. (1997) Sensitivity of Malaria, Schistomiasis and Denghe to Global Warming. Climatic Change, 35, 145-156.

http://dx.doi.org/10.1023/A:1005365413932

Submit or recommend next manuscript to SCIRP and we will provide best service for you:

Accepting pre-submission inquiries through Email, Facebook, LinkedIn, Twitter, etc. A wide selection of journals (inclusive of 9 subjects, more than 200 journals)

Providing 24-hour high-quality service

User-friendly online submission system

Fair and swift peer-review system

Efficient typesetting and proofreading procedure

Display of the result of downloads and visits, as well as the number of cited articles

Maximum dissemination of your research work

Submit your manuscript at: http://papersubmission.scirp.org/

Or contact ajcc@scirp.org 